\title{
Anastomotic Leaks following Esophagectomy for Esophageal and Gastroesophageal Junction Cancer: The Key Is the Multidisciplinary Management
}

\author{
Raquel Ortigão ${ }^{a}$ Brigitte Pereira $^{b}$ Rui Silva $^{a}$ Pedro Pimentel-Nunes ${ }^{a, c}$ \\ Pedro Bastos $^{a}$ Joaquim Abreu de Sousa ${ }^{d}$ Filomena Faria $^{b}$ \\ Mário Dinis-Ribeiro ${ }^{a, c}$ Diogo Libânio ${ }^{a, c}$ \\ aGastroenterology Department, Portuguese Oncology Institute of Porto, Porto, Portugal; b Intensive Care Unit, \\ Portuguese Oncology Institute of Porto, Porto, Portugal; ' $M E D C I D S$, Faculty of Medicine, University of Porto, Porto, \\ Portugal; ${ }^{d}$ Surgery Department, Portuguese Oncology Institute of Porto, Porto, Portugal
}

\section{Keywords}

Esophageal cancer · Esophagectomy · Anastomotic leakage · Endoscopic treatment

\begin{abstract}
Introduction: Anastomotic leakage after esophagectomy is associated with high mortality and impaired quality of life. Aim: The objective of this work was to determine the effectiveness of management of esophageal anastomotic leakage (EAL) after esophagectomy for esophageal and gastroesophageal junction (GEJ) cancer. Methods: Patients submitted to esophagectomy for esophageal and GEJ cancer at a tertiary oncology hospital between 2014 and 2019 ( $n=$ 119) were retrospectively reviewed and EAL risk factors and its management outcomes determined. Results: Older age and nodal disease were identified as independent risk factors for anastomotic leak (adjusted OR 1.06, 95\% Cl 1.001.13, and adjusted OR 4.89, 95\% Cl 1.09-21.8). Patients with EAL spent more days in the intensive care unit (ICU; median 14 vs. 4 days) and had higher 30 -day mortality ( 15 vs. $2 \%$ ) and higher in-hospital mortality ( 35 vs. $4 \%$ ). The first treatment option was surgical in 13 patients, endoscopic in 10, and conservative in 3 . No significant differences were noticeable
\end{abstract}

between these patients, but sepsis and large leakages were tendentially managed by surgery. At follow-up, 3 patients in the surgery group (23\%) and 9 in the endoscopic group $(90 \%)$ were discharged under an oral diet $(p=0.001)$. The inhospital mortality rate was $38 \%$ in the surgical group, $33 \%$ in the conservative group, and $10 \%$ in endoscopic group ( $p=$ 0.132). In patients with EAL, the presence of septic shock at leak diagnosis was the only predictor of mortality $(p=0.004)$. ICU length-of-stay was non-significantly lower in the endoscopic therapy group (median 4 days, vs. 16 days in the surgical group, $p=0.212$ ). Conclusion: Risk factors for EAL may help change pre-procedural optimization. The results of this study suggest including an endoscopic approach for EAL.

\footnotetext{
(C) 2021 Sociedade Portuguesa de Gastrenterologia Published by S. Karger AG, Basel
}

\section{Deiscências anastomóticas após esofagectomia por neoplasia esofágica / juncional: a importância da abordagem multidisciplinar}

Palavras Chave

Cancro esofágico · Esofagectomia · Deiscência anastomótica $\cdot$ Tratamento endoscópico karger@karger.com www.karger.com/pjg

Karger $\stackrel{\text { ' }}{5}$ BOPEN ACCESS (c) 2021 Sociedade Portuguesa de Gastrenterologia. Published by S. Karger AG, Basel

This is an Open Access article licensed under the Creative Commons Attribution-NonCommercial-4.0 International License (CC BY-NC) (http://www.karger.com/Services/OpenAccessLicense), applicable to the online version of the article only. Usage and distribution for commercial purposes requires written permission.
Correspondence to:

Raquel Ortigão, raquel.ortigao@hotmail.com 


\section{Resumo}

Introdução: A deiscência anastomótica após esofagectomia está associada a uma elevada taxa de mortalidade e qualidade de vida comprometida. Objetivo: Avaliar a eficácia da abordagem da deiscência de anastomose esofágica após esofagectomia por neoplasia do esófago e da junção esofagogastrica (JEG). Métodos: Foram revistos retrospetivamente todos os doentes submetidos a esofagectomia por neoplasia do esófago e da JEG num hospital terciário entre 2014 e 2019 ( $n=119)$ e analisados os fatores de risco e as diferentes abordagens na deiscência anastomótica. Resultados: A idade avançada e a presença de metastização ganglionar foram identificados como fatores de risco independentes para deiscência anastomótica (OR 1.06, 95\% IC 1.00-1.13 e 4.89, IC 1.09-21.8). Os doentes com deiscência anastomótica estiveram mais dias internados na unidade de cuidados intensivos (UCI) (mediana 14 vs. 4 dias) e tiveram uma mortalidade aos 30 dias e intra-hospitalar mais elevada ( $15 \%$ vs. $2 \%$ e $35 \%$ vs. $4 \%$, respectivamente). A primeira abordagem terapêutica foi cirúrgica em 13 doentes, endoscópica em 10 e conservadora em 3. Não foram encontradas diferenças estatisticamente significativas entre estes doentes, com uma tendência para a presença de sépsis e de deiscências de maior dimensão nos doentes abordados cirurgicamente. Durante o seguimento, 3 doentes do grupo cirúrgico (23\%) e 9 do grupo endoscópico (90\%) tiveram alta hospitalar sob dieta oral $(p=0.001)$. A taxa de mortalidade intra-hospitalar foi de $38 \%$ no grupo cirúrgico, 33\% no grupo conservador e $10 \%$ no grupo endoscópico ( $p=$ 0.132). Nos doentes com deiscência anastomótica, a presença de choque sético ao diagnóstico foi o único preditor de mortalidade $(p=0.004)$. O tempo de internamento na UCI não foi significativamente menor no grupo submetido a tratamento endoscópico (mediana de 4 dias vs. 16 dias no grupo cirúrgico, $p=0.212$ ). Conclusão: A identificação de fatores de risco para deiscência anastomótica após esofagectomia pode ajudar a alterar a optimização pré-procedimento. Os resultados deste estudo sugerem incluir uma abordagem endoscópica nos doentes com deiscência anastomótica.

@ 2021 Sociedade Portuguesa de Gastrenterologia. Publicado por S. Karger AG, Basel

\section{Introduction}

Esophageal cancer is the sixth leading cause of cancerrelated death overall, mainly due to diagnosis in advanced stages [1]. Even when esophageal cancer is resectable, esophagectomy carries a high risk of death (3.6-4.5\%) compared with most surgically treated cancers [2-4]. Many efforts have been made to improve the esophagectomy technique and to reduce postoperative complications, but esophageal anastomotic leakage (EAL) remains a frequent and feared postoperative complication, associated with high mortality and impaired quality of life. However, improvement of surgical techniques and management of complications has led to a steady decrease in postoperative mortality over the years [5-8].

Some factors have been associated with EAL development, such as patients' nutritional status and comorbidities, cancer stage, surgical procedure, and neoadjuvant therapy, but there are some controversies in the literature about the significant risk factors for this adverse event [9, 10]. The identification of patients at risk for EAL can thus help in postsurgical management.

EAL treatment success relies on early diagnosis, but optimal treatment remains controversial. The treatment decision is dependent on the characteristics of the leak and the severity of the patient's condition. In the past, surgical revision with re-anastomosis or esophageal deviation was the treatment of choice. Since the emergence of endoscopic techniques, several potential endoscopic interventions have been used, such as clipping, self-expandable metal stents (SEMS), endoscopic vacuum therapy (EVT), and endoscopic suturing devices [11-13].

While there are several studies evaluating the success of endoscopic and surgical treatment, there are few comparative studies evaluating treatment outcomes of different management strategies specifically following oncological esophagectomy. The aim of this study was to assess anastomotic leakage rates after esophagectomy for esophageal and gastroesophageal junction cancer (GEJ), to identify possible risk factors for EAL, and compare the outcomes of patients with EAL according to management strategy.

\section{Materials and Methods}

\section{Patients and Methods}

This was a retrospective cohort study including consecutive patients submitted to esophagectomy for esophageal or GEJ cancer between January 2014 and December 2019 in Instituto Português de Oncologia do Porto - Francisco Gentil. All the patients submitted to esophagectomy are initially managed in ICU where an electronic registry of all admissions ensure consecutive sampling. Data collection was performed through analysis of electronic medical records and patient charts.

Patient demographic characteristics were collected along with the following clinical, surgical, and pathological characteristics: 
history of diabetes or hypertension, smoking and alcohol habits, tumor location, histological type, surgical approach (Ivor-Lewis, McKeown, transhiatal, Sweet, and total esophagogastrectomy), type of reconstruction, anastomosis technique, surgeon's experience, year of procedure, clinical TNM stage, neoadjuvant treatment, APACHE II (Acute Physiology and Chronic Health Evaluation) score on the first postoperative day, mean length-of-stay in the intensive care unit (ICU), need for invasive ventilation, inhospital mortality, and 1-year survival rate. Patients with and without EAL were compared in terms of these factors.

\section{Definition and Management of Anastomotic Leaks}

An anastomotic leak was defined as a "full thickness gastrointestinal defect involving the esophagus, anastomosis, staple line, or conduit irrespective of presentation or method of identification" according to the Esophagectomy Complications Consensus Group definition [14]. An anastomotic leak was classified as contained if no communication existed with the pleural space or only minimal extension into the mediastinal space occurred. Contrarily, an uncontained leak was defined as a relatively large amount of contrast extravasating into the pleural space or draining into the chest tube, the presence of an abscess, mediastinitis, pyothorax, and sepsis [15].

The diagnosis of anastomotic leak was made through oral contrast computed tomography (CT), upper digestive endoscopy, or contrast esophagography. The combination of the patient's clinical status with the availability of each exam at the time of suspected diagnosis were the factors with the greatest impact on the selection of the diagnostic exam to be performed. Patient management depended on the characteristics of the leak, clinical status, and the availability of emergent endoscopic facilities, as well as multidisciplinary judgement. Thr treatment strategy was classified as conservative, surgical, and/or endoscopic. Conservative treatment included intravenous antibiotics, restriction of oral intake, and enteral or parenteral nutrition. Surgical (re-operation) treatment included primary repair of the leak with decortication and drainage, resection of the leak with re-anastomosis, as well as esophageal deviation with cervical esophagostomy. Endoscopic treatment included through-the-scope (TTS) endoclip, over-the-scope clip (OTSC), SEMS, or EVT.

Successful closure of the leak was defined as the state in which endoscopy, CT, or contrast esophagography confirmed complete healing and the patient presented no clinical signs of leak. Time to oral intake was defined as the period from the first treatment of the leak to the day of oral diet start, with oral intake being progressively resumed except if diagnostic exams evidenced persistent leak. Patients who died before starting oral intake were not included in this analysis. A failure to seal the leak was defined as persistent leak after the end of treatment or the need of another treatment strategy. Time to oral intake, ICU length-of-stay, and inhospital mortality were compared between the conservative, endoscopic, and surgical treatment group. ICU length-of-stay was calculated excluding patients who died during ICU stay.

\section{Statistical Analysis}

All statistical analyses were performed using IBM SPSS version 26. Data are presented as the number and percentages for categorical variables. Continuous variables are presented as the mean and standard deviation (SD) or as the median and interquartile range (Q25-Q75). Univariable analysis was performed using the $\chi^{2}$ test or Fisher exact test, while continuous variables were compared using Student's $t$ test or Mann-Whitney test if non-parametric data. The multivariable model included age, sex, and variables with $p<$ 0.2 in univariable analysis. For all comparisons, $p<0.05$ was considered to indicate statistical significance.

\section{Results}

\section{Patients}

From January 2014 to December 2019, 119 patients underwent esophagectomy for esophageal and GEJ cancer. We excluded 4 patients from the analysis ( 3 patients with late esophageal pulmonary fistulas more than 1 year after esophagectomy, and 1 patient who had esophageal melanoma metastasis), except for incidence rate measurement.

All the patients were admitted to ICU after surgery for intensive medical surveillance. Patients were predominantly male (85.2\%) and the mean age was 64.1 years (SD 9.2). Squamous cell carcinoma was the most frequent histology $(77 / 115,67.0 \%)$, with adenocarcinomas accounting for $33.0 \%$. In more than half of the patients $(52.2 \%)$, the tumor did not extend beyond the muscularis propria ( $\leq \mathrm{T} 2)$. Seventy-nine patients $(68.7 \%)$ had disease at least in one lymph node $(\mathrm{N}+)$.

Eighty-four patients $(73.0 \%)$ received neoadjuvant chemoradiation therapy. The esophagectomy was performed through the McKeown approach in 80 (69.6\%), transhiatal approach in 15 (13.0\%), Ivor-Lewis approach in $12(10.4 \%)$, Sweet approach in $6(5.2 \%)$, and total esophagogastrectomy in $2(1.7 \%)$.

The esophagectomy was performed with cervical anastomosis in 98 patients and with intrathoracic anastomosis in 21 patients. The stomach was used as a conduit to reestablish gastrointestinal continuity in 100 cases (gastric pull-up). The esophageal anastomosis was hand sewn in $71.6 \%$, mechanical in $22.1 \%$, and hybrid in $6.3 \%$. Table 1 shows the clinicopathological and surgical characteristics of the patients.

\section{Incidence and Characteristics of Anastomotic Leakage}

Considering all patients submitted to esophagectomy $(n=119), 26$ patients $(21.8 \%)$ had an anastomotic leak. There were no significant differences according to anastomosis location (21/95 in cervical location vs. 5/20 in intrathoracic, $p=0.988)$. The leak rate was stable throughout the study period.

The median time interval from surgery to diagnosis of the anastomotic leakage was 5.5 days (IQR 3-11). At the
Ortigão et al. 
Table 1. Clinicopathological and surgical data of patients who underwent esophagectomy and differences between those developing leaks

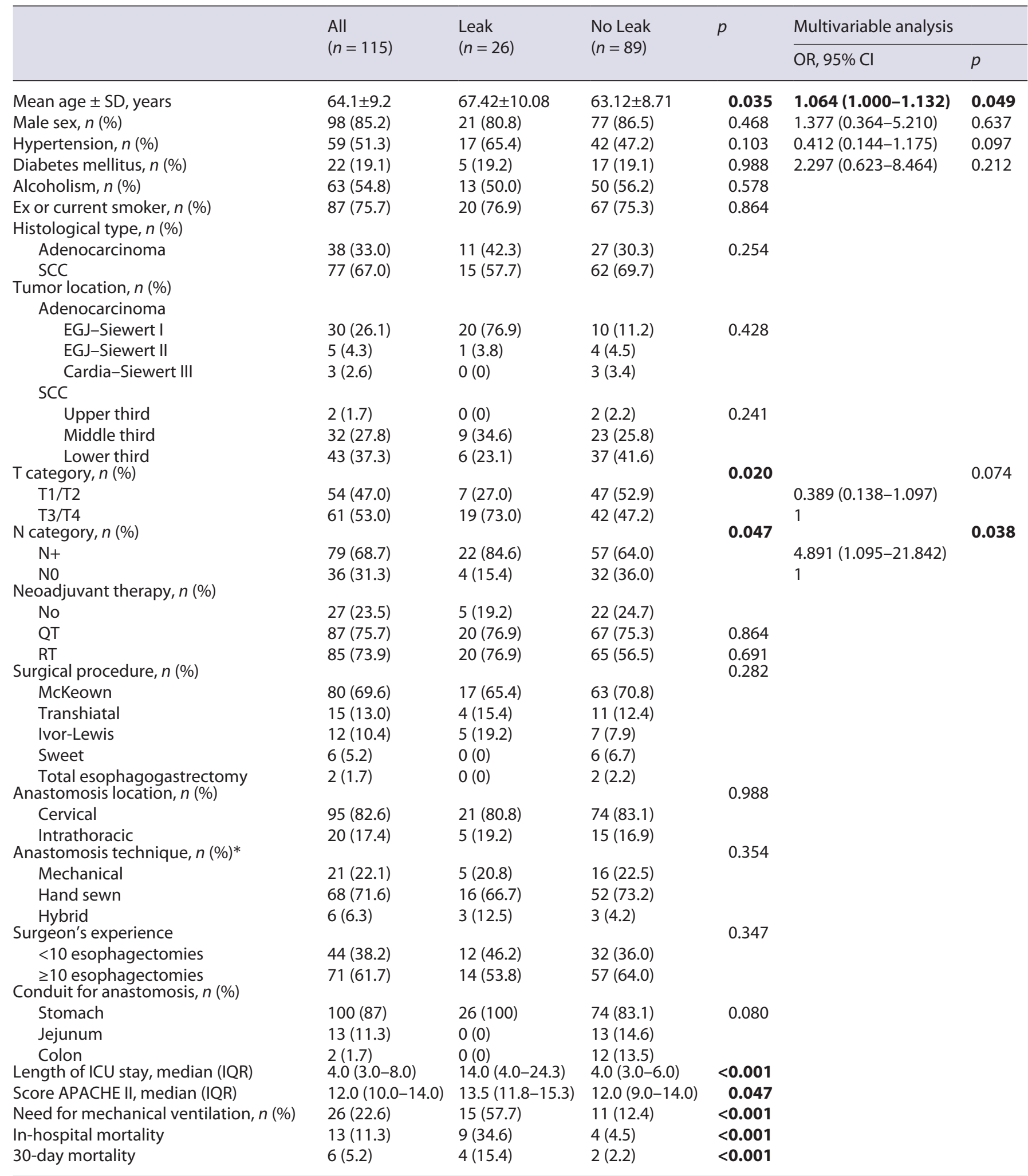

IQR, interquartile range; SCC, squamous cell carcinoma; EGJ, esophagogastric junction. N+ refers to N1-N3 regional lymph node tumor extension, according to TNM classification. Bold values are significant. * Anastomosis technique was not registered in 20 patients. 


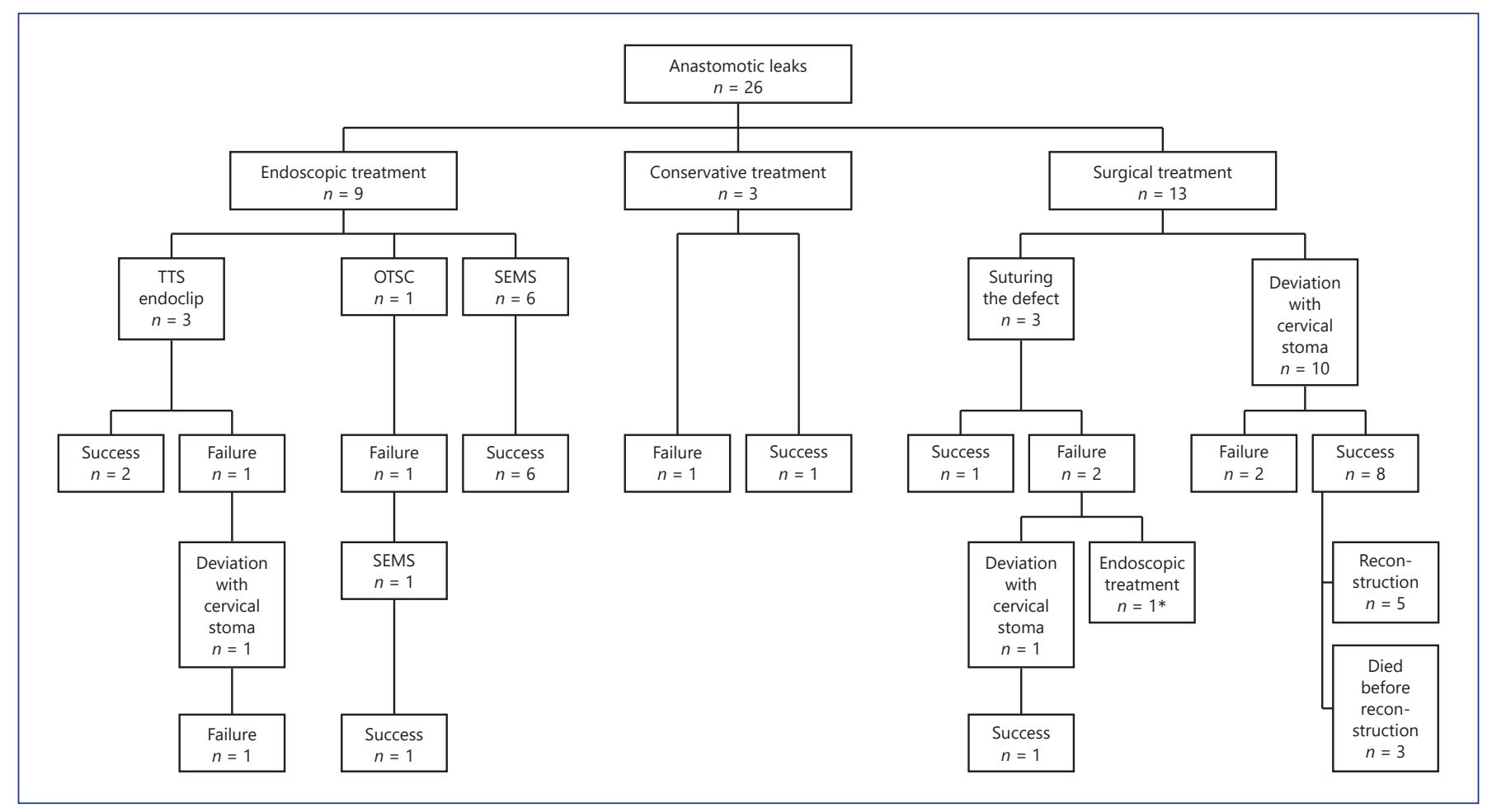

Fig. 1. Management of patients with EAL. * Initially two OTSC, followed by placement of two SEMS and EVT. TTS, through-the-scope clip; OTSC, over-the-scope clip; SEMS, self-expandable metal stents; EVT, endoscopic vacuum therapy.

time of diagnosis, the mean C-reactive protein was $268 \pm$ $103 \mathrm{mg} / \mathrm{L}$. Thirteen patients (50\%) developed septic shock due to EAL.

The EAL was most of the times diagnosed through radiological exams (12 by CT, 3 by radiographic contrast examination) and in 11 patients by upper digestive endoscopy. The leak size was described in 21 patients. Eight patients had a defect of less than $25 \%$ of anastomotic circumference, 9 patients had a defect up to $25-50 \%$, and 4 had a defect $>50 \%$. In 1 patient the leakage was associated with esophago-respiratory fistula.

The leak was limited to the mediastinum in 15 patients (57.7\%), of which 10 were contained. The remaining 5 were considered uncontained with mediastinitis. The leak extended into the pleural space in 11 patients $(42.3 \%)$, all being considered non-contained. During the followup period, 3 patients had fistula formation.

\section{Risk Factors for Anastomotic Leak}

Univariable analysis revealed that EAL was significantly associated with older age $(p=0.035)$, T and $\mathrm{N}$ tumor category (OR 3.037 [1.161-7.943] and OR 3.088
[1.078-9.751], respectively). Multivariable analysis revealed that age and nodal disease were independent risk factors for EAL (Table 1).

Patients with EAL spent more days in the ICU than patients without leak (median 14 vs. 4 days, respectively; $p<0.001)$. The median APACHE II score on postoperative day 1 was significantly higher in patients with leak (13.5 vs. $12.0, p=0.047$ ). In-hospital mortality (34.6 vs. $4.5 \%)$ and 30 -day mortality (15.4 vs. $2.2 \%)$ were significantly higher in the leak group (OR 11.25 [3.10-40.78] and OR 7.909 [1.36-46.00], respectively). Also, APACHE II score on postoperative day 1 was significantly associated with in-hospital mortality $(p=0.007)$.

\section{Treatment Strategy}

Fourteen patients needed surgical reintervention, one after failure of endoscopic treatment (Fig. 1). The leak was revised by suturing the defect in 3 patients, with successful closure in 1 patient. Ten patients were treated by surgical deviation, taking down the conduit and creating a cervical stoma. After this procedure, 3 patients died during hospitalization ( 2 of them in the first 30 days). Five
Ortigão et al. 
Table 2. Characteristics of patients submitted to endoscopy and surgery

\begin{tabular}{llll}
\hline & $\begin{array}{l}\text { Surgical treatment } \\
(n=13)\end{array}$ & $\begin{array}{l}\text { Endoscopic treatment } \\
(n=10)\end{array}$ & $p$ \\
\hline Age, mean \pm SD, years & $65.0 \pm 11.6$ & $69.0 \pm 10.0$ & 0.185 \\
Male sex, $n$ (\%) & $11(84.6)$ & $8(80.0)$ & 0.772 \\
Score APACHE II, median (IQR) & $14.0(12.0-16.5)$ & $13.0(9.8-15.8)$ & 0.471 \\
C-reactive-protein, mean \pm SD, mg/L & $277.6 \pm 91.4)$ & $252.0 \pm 118.8)$ & 0.564 \\
Septic shock, $n$ (\%) & $9(69.2)$ & $3(30.0)$ & 0.062 \\
Leak location, $n(\%)$ & & & 0.099 \\
$\quad$ Cervical & $6(46.2)$ & $8(80.0)$ & \\
$\quad$ Thoracic & $7(53.8)$ & $2(20.0)$ & \\
Leakage size ${ }^{1}, n(\%)$ & & & \\
$\quad<25 \%$ & $2 / 10(20.0)$ & $5 / 9(55.5)$ & 0.113 \\
$\quad 25-50 \%$ & $5 / 10(50.0)$ & $4 / 9(44.4)$ & 0.580 \\
$\quad>50 \%$ & $3 / 10(30.0)$ & $0 / 9(0.0)$ & $5(50.0)$ \\
Cavity drainage, $n(\%)$ & $8(61.5)$ & & \\
\hline
\end{tabular}

${ }^{1}$ In the surgical group, leak size was described in 9 of 13 patients, and in the endoscopic group in 9 of 10 patients. patients underwent new anastomosis reconstruction, which was performed during the same hospitalization in 2 patients and both were discharged under an oral diet. In the other 3 patients reconstruction was carried out electively and 1 of them died 5 days after the procedure with mediastinitis as a result of new leak. One patient developed stenosis after reconstruction (1/4).

Endoscopic treatment was chosen as the primary treatment in 10 patients. TTS-endoclips were used in 3 patients, OTSC in 1 patient, and SEMS in 6 patients. TTSendoclips were only used in small leaks (less than $10 \mathrm{~mm}$ ), with success in 2 of the 3 patients. OTSC was used as the first treatment in only 1 patient with a leak with $15 \mathrm{~mm}$. Due to persistent leakage a SEMS was placed 1 week later with success.

Endoscopic stenting was used as first-line therapy in 6 patients (4 partially covered SEMS and 2 fully covered SEMS) and as rescue treatment in 2 patients (1 fully covered SEMS and 1 partially covered SEMS). Technical placement of the stent was successful in all cases. All the patients who received endoscopic stenting as first treatment had clinical success and started oral intake before hospital discharge.

Complications related to stent insertion occurred in 5 patients (62.5\%): 2 cases of stent migration (1 fully covered SEMS and 1 partially covered SEMS) and 3 cases of esophageal stenosis ( 3 partially covered SEMS). One of the stent migrations was successfully managed with endoscopic repositioning and the other patient was managed with removal and insertion of another stent. All stents were removed between 4 and 8 weeks after placement.

Esophageal Anastomotic Leakage
EVT was used in 1 patient. This patient was initially submitted to surgical reintervention (suture of anastomosis) without success, and subsequently endoscopic treatment was performed, first with 2 OTSC and then with placement of 2 fully covered SEMS. After 38 days of hospitalization the patient was discharged on an oral diet. Two months later the patient returned to the hospital to have the stents removed and EAL with mediastinum contamination was diagnosed. EVT was used as rescue therapy. Thirteen sponges were used and the treatment lasted 31 days. The patient needed hospitalization for 74 days. One month after leak healing the patient started endoscopic dilatation due to esophageal stenosis.

\section{Outcomes according to Treatment Strategy}

In brief, the initial management was conservative in 3 patients, endoscopical treatment in 10 patients, and surgical in 13 patients (Fig. 1). Concomitant drainage of an infected cavity was performed in 50\% of endoscopictreated patients (4 percutaneous drainage and 1 surgical drainage) and in $62 \%$ of surgical group ( 7 drainage at the time of surgery and 1 percutaneous drainage).

The patient demographics (age and sex), clinical severity variables (PCR at the diagnosis of leak, APACHE II score on postoperative day, presence of septic shock) and leak characteristics (leak location and size and presence of a concomitant cavity) did not significantly differ between patients submitted to endoscopic and surgical treatment (Table 2). Patients submitted to conservative treatment were excluded from this analysis because of its small size. 
Table 3. Outcomes after anastomotic leak according to treatment

\begin{tabular}{|c|c|c|c|c|}
\hline Primary treatment & $\begin{array}{l}\text { Conservative treatment } \\
(n=3)\end{array}$ & $\begin{array}{l}\text { Endoscopic treatment } \\
(n=10)\end{array}$ & $\begin{array}{l}\text { Surgical treatment } \\
(n=13)\end{array}$ & $p^{\mathrm{e}}$ \\
\hline Discharge under oral intake, $n(\%)$ & $2(66.7)$ & $9(90)$ & $3(23.1)$ & 0.001 \\
\hline Length of ICU stay ${ }^{\mathrm{b}}$, median (IQR), days & $27(12-68)$ & $4(3-13.5)$ & $16(6.3-24.0)$ & 0.212 \\
\hline Length of hospital stay ${ }^{c}$, median (IQR), days & $36 ; 207^{d}$ & $36(21-56.5)$ & $35(23.8-52)$ & 0.885 \\
\hline
\end{tabular}

IQR, interquartile range. Bold values are significant. ${ }^{a}$ Patients who died before starting oral intake were not included in this analysis

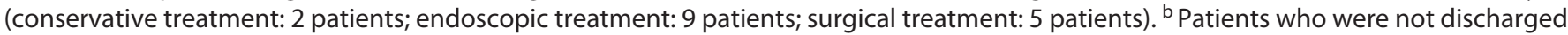
from the ICU were excluded (conservative treatment: 3 patients; endoscopic treatment: 10 patients; surgical treatment: 10 patients). c Patients who died during hospitalization were excluded (conservative treatment: 2 patients; endoscopic treatment: 9 patients; surgical treatment: 8 patients). ${ }^{\mathrm{d}}$ Absolute numbers presented (sample of 2 patients). ${ }^{\mathrm{e}}$ Analysis of statistically significant differences between patients submitted to endoscopic and surgical treatment.

Table 4. Predictors of mortality and prolonged hospital stay

\begin{tabular}{|c|c|c|c|c|c|c|}
\hline & \multicolumn{2}{|l|}{ Mortality } & $p$ & \multicolumn{2}{|c|}{ Prolonged hospital stay ( $\geq 30$ days) ${ }^{1}$} & $p$ \\
\hline Age, mean $\pm S D$, years & $71.6 \pm 8.0$ & $65.6 \pm 11.3$ & 0.203 & $64.3 \pm 8.7$ & $68.0 \pm 16.3$ & 0.673 \\
\hline Male sex, $n(\%)$ & $7(100.0)$ & $15(78.9)$ & 0.187 & $11(84.6)$ & $4(66.7)$ & 0.372 \\
\hline Score APACHE II, median (IQR) & $15.0(12.0-17.0)$ & $12.0(10.0-15.0)$ & 0.210 & $13.0(10.0-14.5)$ & $12.0(10.5-16.5)$ & 0.894 \\
\hline Leak location, $n(\%)$ & & & 0.780 & & & 0.419 \\
\hline Cervical & $4(57.1)$ & $12(63.2)$ & & $9(69.2)$ & $3(50.0)$ & \\
\hline Thoracic & $3(42.9)$ & $7(36.8)$ & & $4(30.8)$ & $3(50.0)$ & \\
\hline Leakage size ${ }^{2}, n(\%)$ & & & 0.911 & & & 0.680 \\
\hline$<25 \%$ & $3 / 7(42.9)$ & $5 / 14(35.7)$ & & $3 / 10(30.0)$ & $2 / 4(50.0)$ & \\
\hline $25-50 \%$ & $3 / 7(42.9)$ & $6 / 14(42.8)$ & & $5 / 10(50.0)$ & $1 / 4(25.0)$ & \\
\hline Surgical & $5(71.4)$ & $8(42.1)$ & & $6(46.2)$ & $2(33.3)$ & \\
\hline Conservative & $1(14.3)$ & $2(10.5)$ & & $1(7.7)$ & $1(16.7)$ & \\
\hline
\end{tabular}

The bold value is significant.

${ }^{1}$ Patients who died during hospitalization were excluded. ${ }^{2}$ Leak size was described in 21 patients.

Outcomes between the conservative, endoscopic and surgical treatment regarding time to oral diet, length of ICU and hospital stay, and in-hospital mortality are summarized in Table 3. The median ICU length-of-stay was non-significantly longer in the surgical group (16 days) compared to the endoscopic group ( 4 days; $p=0.212$ ), but the median hospital length-of-stay was similar in both groups (36 days in endoscopic group vs. 35 days in surgi- cal group). There were no predictive factors for prolonged hospital stay (Table 4).

Excluding patients who died during hospitalization, oral intake before discharge was possible in 15 patients, 2 (100\%) in the conservative group, $9(100 \%)$ in the endoscopy group, and 3 (60\%) in the surgery group. The other 2 patients in the surgical group were discharged under enteral feeding by tube jejunostomy. The median time 
interval to oral intake was 10 days (3-14) after endoscopic treatment and 35 days (11-262.5) after surgical treatment $(p=0.030)$.

Overall, in-hospital mortality was $33.3 \%(1 / 3)$ in the conservative group, $10 \%(1 / 10)$ in the endoscopic group, and $38.4 \%(5 / 13)$ in the surgical group. The only predictor of mortality following EAL was the presence of septic shock at leak diagnosis $(p=0.004$; Table 4$)$.

Follow-up was complete in all 17 survivors and ranged from 1.3 to 6.2 years. The 1 -year survival rate was $88.2 \%$.

\section{Discussion}

Esophagectomy remains a challenging and difficult surgical procedure, associated with important mortality. In our cohort, the 30 -day mortality rate was $5.2 \%$, with patients with EAL responsible for two thirds. In addition, in-hospital mortality was greater among patients with EAL (34.6\%) compared to those without this complication $(4.5 \%)$. The overall anastomotic leakage rate of $21.8 \%$ observed in our center is in agreement with previous studies (rates ranging from 6 to 30\%) [3, 16-18]. Identifying possible risk factors for esophageal leak may provide opportunities to improve preoperative patient conditions and also to choose the most adequate surgical procedure.

A correlation between higher age and EAL was found in univariate and multivariate analysis. However, most previous studies have not found a significant correlation between age and EAL $[19,20]$.

Patients with hypertension, diabetes mellitus, and alcoholic or smoking habits were not significantly predisposed to EAL, although there seems to be a tendency for hypertension among those with leak. These results are not consistent with previous studies $[19,21]$. In fact, Kassis et al. [3] identified various risk factors, such as congestive heart failure, coronary and peripheral artery disease, smoking habits, and cervical anastomosis, all of them with a potential to compromise microvascular supply to the healing of anastomosis. T and $\mathrm{N}$ categories of clinical TNM staging were both risk factors for EAL. A possible explanation for this association may be the fact that these patients may require a longer and more extensive surgery.

In agreement with the remaining literature, we also did not find neoadjuvant therapy as a risk factor for anastomotic leak $[3,19,22,23]$. Since clinical T3 or T4 and the presence of regional lymph node metastasis at diagnosis were significantly associated with EAL, TNM reassess- ment after neoadjuvant therapy would allow for further understanding of the impact of neoadjuvant therapies on the postoperative prognosis.

The surgical procedure and surgeon's experience were not significantly associated with EAL. However, patients submitted to Ivor-Lewis had a higher rate of EAL (41.7\%) than patients submitted to the McKeown procedure $(21.3 \%)$. The anastomosis technique was not a risk factor for EAL, as described in a meta-analysis published in 2014 . However, $67 \%$ of the EAL patients had hand-sewn esophagogastric anastomosis [24]. A recent systematic review with meta-analysis revealed that patients undergoing a transthoracic approach were associated with significantly lower rates of EAL [23]. Surprisingly, in our study, the EAL rate was similar in patients with intrathoracic anastomosis (25\%) compared with cervical anastomosis (22.1\%). These results may be due to the limited number of intrathoracic anastomosis. In fact, many surgeons prefer a cervical anastomosis since a wider oncological resection margin can be achieved and eventual anastomosis dehiscence is usually less severe.

EAL was significantly associated with an increased length of ICU stay and in-hospital mortality. We only measured the APACHE II score on the first day after surgery, therefore it does not reflect patient status at the time of leak diagnosis. Even so, patients with higher APACHE II scores revealed a higher risk of EAL, which means that these patients on the first postoperative day already had clinical and analytical changes that raise the hypothesis of a surgical complication. According to our results, a higher APACHE II score should influence the time of surveillance in ICU. Schniewind et al. [25] recorded patients' APACHE II scores at the time of treatment initiation. In this study, the APACHE II score were 14, 15, 11, and 5 in the EVT, surgery, SEMS, and conservative groups, elucidating that patients with a higher score needed a more interventional treatment.

Currently, there is no standardized treatment algorithm for patients with EAL. The management of EAL should be individualized and guided by the magnitude of the leak and the severity of the clinical condition. The therapeutic decision also depends on medical preferences of the physician in charge and the availability of treatment at the time of diagnosis. Some authors suggested possible therapeutic strategies. Patients with asymptomatic localized radiological cervical leak could be managed conservatively [26]. In addition, endoscopic clipping may be a successful treatment for small leaks, but in larger defects its efficacy is limited. In the most 
severe cases, two major therapeutics have been encouraged: insertion of SEMS or surgical exploration. A systematic review published in 2017 suggested SEMSbased therapy as an alternative to surgical treatment, excluding cases such as patients with anatomical leaks unfit for SEMS, patients with endoscopic signs of conduit necrosis, or septic patients. They concluded that the overall postprocedural in-hospital mortality is at least double that following SEMS introduction [27]. In our cohort study, in 8 patients the medical team decided to use SEMS (6 as the first-treatment and 2 as second-line therapy). Complete healing of the leak was achieved in 7 patients (success rate of $87.5 \%$ ), similar to reported in previous studies (ranging from 70 to $81 \%$ ) [27-29]. In 1 patient, the stent was introduced late in the course of the disease, which may explain the therapeutic failure. Esophageal stenosis was the most common complication related to stent removal and occurred in 3 patients (37.5\%). All of them occurred in patients with partially covered SEMS. Stent migration occurred in 2 patients (25\%). Despite the small number of patients with SEMS, the rate of complications related to stent insertion are in line with previous studies [30].

Recently, EVT has been described as a new effective treatment option. In contrast to stent placement, EVT requires multiple endoscopic procedures. In our study, the only patient treated with EVT needed 10 endoscopies in only 1 month. Nevertheless, EVT allows visualizing the wound cavity and optimal drainage, being very effective on sepsis control in patients with mediastinitis. A metaanalysis published in 2020 compared EVT and SEMS for EAL and revealed a significantly higher success rate of EVT in healing EAL, a shorter duration of treatment, and a lower in-hospital mortality rate [12].

In our series, 3 patients were submitted to leak suture, with successful closure in only 1 of them. Ten patients were treated with surgical deviation by taking down the conduit if not viable and creating a cervical stoma. Three patients died during hospitalization due to sepsis. The other 7 patients had hospital discharge, 2 with anastomosis reconstruction and 5 with jejunostomy. Although the leak is easily controlled with this procedure, the right time to perform esophageal reconstruction is a difficult decision, forcing patients to remain on an artificial diet sometimes for more than a year. In the operative group, $61.5 \%$ died before starting oral intake. The time to oral intake was significantly longer in the surgical group when compared to the endoscopic group. Crestanello et al. [16], described the management of 47 patients with EAL. A surgical approach was made in 20 patients and esophageal diversion was the chosen procedure in only 2 patients. Reinforcement of the anastomosis and anastomotic repair were the most performed procedures. In-hospital mortality was lower (15\%) compared with rates observed in our center.

Despite the small number of patients in each treatment group, there were no statistically significant differences between the groups of patients treated surgically and endoscopically. However, there was a tendency towards surgical treatment in patients with dehiscence of more than $50 \%$ of the circumference of the anastomosis or with septic shock. It is noteworthy in our study that a higher rate of in-hospital mortality was observed in patients who underwent surgical intervention $(38.5 \%)$ as compared with endoscopic (10\%) and conservative treatments (33\%). Taking into account the outcomes of the leak patients, we consider that surgical intervention is indicated for patients with dehiscence of $>75 \%$ of the anastomosis, unstable patients, or when endoscopic treatment fails.

The retrospective nature of our cohort presented limitations mainly in the collection of potential risk factors. An example is nutritional status data, such as weight and albumin, which were not consistently recorded pre-ICU admission. The same applies to history of cardiac arrhythmia or chronic obstructive pulmonary disease, clinical factors associated with leak occurrence previously in the literature. Given that diagnostic exams and therapeutic decisions are dependent on medical judgement and equipment availability, there may be regional differences in the decision-making standards. This unicenter design could therefore limit the generalizability of findings.

Considering the postoperatory mortality rate in our cohort, identification of risk factors for EAL may help change preoperative management.

We recommend that once EAL is diagnosed, individualized treatment should be given according to the size of the leak, extent of the contaminated cavity, and status of the patient. Analysis of EAL treatment favors, in our opinion, endoscopic treatment instead of an aggressive approach. Further investigation is needed to determine which factors make us decide for endoscopic treatments, mainly SEMS and EVT, instead of surgical approach.

\section{Statement of Ethics}

The study was reviewed and approved by the local ethics committee (Comissão de Ética e Saúde do IPO-Porto).
Ortigão et al. 


\section{Conflict of Interest Statement}

The authors have no conflicts of interest to declare.

\section{Funding Sources}

The authors have not declared a specific grant for this research from any funding agency in the public, commercial, or not-forprofit sectors.

\section{Author Contributions}

R.O. and D.L. designed the study; R.O. and F.F. participated in the acquisition of the data; R.O. participated in the analysis and interpretation of the data and drafted the initial manuscript; D.L., B.P., R.S., P.P.-N., P.B., J.A.d.S., and M.D.-R. revised the article critically for important content.

\section{Data Availability Statement}

All data generated or analyzed during this study are included in this article. Further enquiries can be directed to the corresponding author.

\section{References}

1 Bray F, Ferlay J, Soerjomataram I, Siegel RL, Torre LA, Jemal A. Global cancer statistics 2018: GLOBOCAN estimates of incidence and mortality worldwide for 36 cancers in 185 countries. CA Cancer J Clin. 2018 Nov;68(6):394-424.

2 Schieman C, Wigle DA, Deschamps C, Nichols Iii FC, Cassivi SD, Shen KR, et al. Patterns of operative mortality following esophagectomy. Dis Esophagus. 2012 SepOct;25(7):645-51.

3 Kassis ES, Kosinski AS, Ross P Jr, Koppes KE, Donahue JM, Daniel VC. Predictors of anastomotic leak after esophagectomy: an analysis of the society of thoracic surgeons general thoracic database. Ann Thorac Surg. 2013 Dec;96(6):1919-26.

4 Yibulayin W, Abulizi S, Lv H, Sun W. Minimally invasive oesophagectomy versus open esophagectomy for resectable esophageal cancer: a meta-analysis. World J Surg Oncol. 2016 Dec;14(1):304.

5 Lagarde SM, de Boer JD, ten Kate FJ, Busch OR, Obertop H, van Lanschot JJ. Postoperative complications after esophagectomy for adenocarcinoma of the esophagus are related to timing of death due to recurrence. Ann Surg. 2008 Jan;247(1):71-6.

6 Low DE. Evolution in surgical management of esophageal cancer. Dig Dis. 2013;31(1):219.

7 Mariette C, Markar SR, Dabakuyo-Yonli TS, Meunier B, Pezet D, Collet D, et al.; Fédération de Recherche en Chirurgie (FRENCH) and French Eso-Gastric Tumors (FREGAT) Working Group. Hybrid Minimally Invasive Esophagectomy for Esophageal Cancer. N Engl J Med. 2019 Jan;380(2):152-62.

8 Schuchert MJ, Abbas G, Nason KS, Pennathur A, Awais O, Santana M, et al. Impact of anastomotic leak on outcomes after transhiatal esophagectomy. Surgery. 2010 Oct;148(4):831-8.
9 Aoyama T, Atsumi Y, Hara K, Tamagawa H, Tamagawa A, Komori K, et al. Risk factors for postoperative anastomosis leak after esophagectomy for esophageal cancer. In Vivo. 2020 Mar-Apr;34(2):857-62.

10 Hall BR, Flores LE, Parshall ZS, Shostrom VK, Are C, Reames BN. Risk factors for anastomotic leak after esophagectomy for cancer: A NSQIP procedure-targeted analysis. J Surg Oncol. 2019 Sep;120(4):661-9.

11 Hampe J, Schniewind B, Both M, FritscherRavens A. Use of a NOTES closure device for full-thickness suturing of a postoperative anastomotic esophageal leakage. Endoscopy. 2010 Jul;42(7):595-8.

12 Scognamiglio P, Reeh M, Karstens K, Bellon E, Kantowski M, Schön G, et al. Endoscopic vacuum therapy versus stenting for postoperative esophago-enteric anastomotic leakage: systematic review and meta-analysis. Endoscopy. 2020 Aug;52(8):632-42.

13 Grimminger PP, Goense L, Gockel I, Bergeat D, Bertheuil N, Chandramohan SM, et al. Diagnosis, assessment, and management of surgical complications following esophagectomy. Ann NY Acad Sci. 2018 Dec;1434(1):25473.

14 Low DE, Alderson D, Cecconello I, Chang AC, Darling GE, D’Journo XB, et al. International Consensus on Standardization of Data Collection for Complications Associated With Esophagectomy: Esophagectomy Complications Consensus Group (ECCG). Ann Surg. 2015 Aug;262(2):286-94.

15 Guo J, Chu X, Liu Y, Zhou N, Ma Y, Liang C. Choice of therapeutic strategies in intrathoracic anastomotic leak following esophagectomy. World JSurg Oncol.2014Dec;12(1):402.

16 Crestanello JA, Deschamps C, Cassivi SD, Nichols FC 3rd, Allen MS, Schleck C, et al. Selective management of intrathoracic anastomotic leak after esophagectomy. J Thorac Cardiovasc Surg. 2005 Feb;129(2):254-60.
17 Gronnier C, Tréchot B, Duhamel A, Mabrut JY, Bail JP, Carrere N, et al.; FREGAT Working Group-FRENCH-AFC. Impact of neoadjuvant chemoradiotherapy on postoperative outcomes after esophageal cancer resection: results of a European multicenter study. Ann Surg. 2014 Nov;260(5):764-70.

18 Zhai C, Liu Y, Li W, Xu T, Yang G, Lu H, et al. A comparison of short-term outcomes between Ivor-Lewis and McKeown minimally invasive esophagectomy. J Thorac Dis. 2015 Dec;7(12):2352-8

19 Gooszen JA, Goense L, Gisbertz SS, Ruurda JP, van Hillegersberg R, van Berge Henegouwen MI. Intrathoracic versus cervical anastomosis and predictors of anastomotic leakage after oesophagectomy for cancer. Br J Surg. 2018 Apr;105(5):552-60.

20 Van Daele E, Van de Putte D, Ceelen W, Van Nieuwenhove Y, Pattyn P. Risk factors and consequences of anastomotic leakage after Ivor Lewis oesophagectomy. Interact Cardiovasc Thorac Surg. 2016 Jan;22(1):32-7.

21 Aminian A, Panahi N, Mirsharifi R, Karimian F, Meysamie A, Khorgami Z, et al. Predictors and outcome of cervical anastomotic leakage after esophageal cancer surgery. J Cancer Res Ther. 2011 Oct-Dec;7(4):448-53.

22 Cooke DT, Lin GC, Lau CL, Zhang L, Si MS, Lee J, et al. Analysis of cervical esophagogastric anastomotic leaks after transhiatal esophagectomy: risk factors, presentation, and detection. Ann Thorac Surg. 2009 Jul;88(1):17784.

23 Kamarajah SK, Lin A, Tharmaraja T, Bharwada Y, Bundred JR, Nepogodiev D, et al. Risk factors and outcomes associated with anastomotic leaks following esophagectomy: a systematic review and meta-analysis. Dis Esophagus. 2020 Mar;33(3):33.

24 Castro PM, Ribeiro FP, Rocha AF, Mazzurana M, Alvarez GA. Hand-sewn versus stapler esophagogastric anastomosis after esophageal ressection: systematic review and meta-analysis. Arq Bras Cir Dig. 2014 JulSep;27(3):216-21. 
25 Schniewind B, Schafmayer C, Voehrs G, Egberts J, von Schoenfels W, Rose T, et al. Endoscopic endoluminal vacuum therapy is superior to other regimens in managing anastomotic leakage after esophagectomy: a comparative retrospective study. Surg Endosc. 2013 Oct;27(10):3883-90.

26 Larburu Etxaniz S, Gonzales Reyna J, Elorza Orúe JL, Asensio Gallego JI, Diez del Val I, Eizaguirre Letamendia E, et al. Cervical anastomotic leak after esophagectomy: diagnosis and management. Cir Esp. 2013 Jan;91(1):317.
27 Persson S, Rouvelas I, Irino T, Lundell L. Outcomes following the main treatment options in patients with a leaking esophagus: a systematic literature review. Dis Esophagus. 2017 Dec;30(12):1-10.

28 Plum PS, Herbold T, Berlth F, Christ H, Alakus $\mathrm{H}$, Bludau $\mathrm{M}$, et al. Outcome of self-expanding metal stents in the treatment of anastomotic leaks after Ivor Lewis esophagectomy. World J Surg. 2019 Mar;43(3):862-9.
29 Dasari BV, Neely D, Kennedy A, Spence G, Rice P, Mackle E, et al. The role of esophageal stents in the management of esophageal anastomotic leaks and benign esophageal perforations. Ann Surg. 2014 May;259(5):852-60.

30 van Boeckel PG, Sijbring A, Vleggaar FP, Siersema PD. Systematic review: temporary stent placement for benign rupture or anastomotic leak of the oesophagus. Aliment Pharmacol Ther. 2011 Jun;33(12):1292-301. 